\title{
Vind genesing van emosionele pyn
}

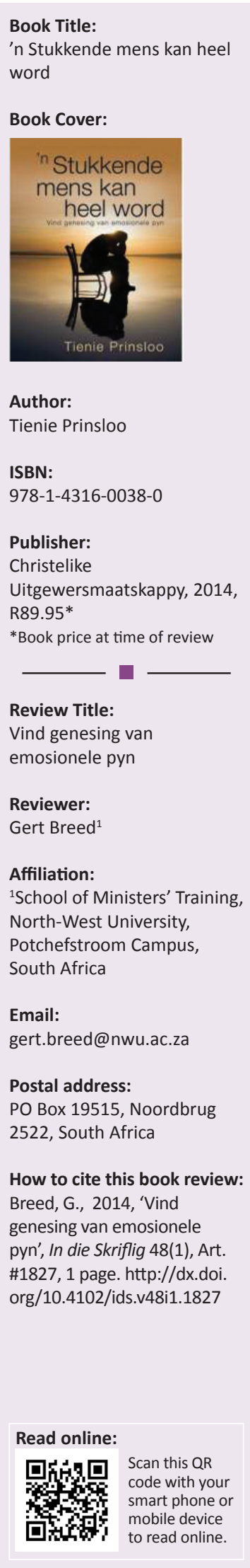

Die boek is in eenvoudige en verstaanbare taal geskryf en hanteer' $n$ wye verskeidenheid aspekte van emosionele pyn. Hoofstuk 1 handel oor die oorsake van emosionele pyn. Die hoofstuk handel hoofsaaklik oor trauma en daar word nie duidelik onderskeid getref tussen trauma en die feit dat alle emosionele pyn nie noodwendig uit trauma voortvloei nie. Dit sou ondervang kon gewees het as die skrywer heel aan die begin baie duidelik gesê het wat hy onder trauma verstaan. Die gevolge van onverwerkte trauma word ook vanuit 'n verskeidenheid hoeke bespreek. Ondanks hierdie tekortkoming gee die hoofstuk goeie inligting en kan dit vir gewone lesers duidelikheid bring oor die oorsake van die emosionele pyn wat hulle beleef. Hoofstuk 2 dra die opskrif 'Pad na genesing'. Die hoofstuk handel egter uit en uit oor geloofsekerheid en regverdigmaking deur die geloof. Dit wil voorkom asof die skrywer glo dat die kom tot geloofsekerheid en daarmee saam die begrip dat ons ten volle in die bloed van Christus gereinig is die volle pad na genesing beskryf. In later hoofstukke word hierop teruggekom. In hoofstuk drie word oor die baie belangrike saak van skuldgevoelens gehandel. Belangrike vrae oor hoe skuldgevoelens hanteer behoort te word, word goed aangespreek. Hoofstuk 4 spreek bitterheid as gevolg van benadeling deur ander op 'n deeglike wyse aan. Hoofstuk 5 handel oor vergifnis wat genesing bring. Dit wat in hoofstuk 2 begin kop uitsteek het, word in hierdie hoofstuk baie duidelik met die voorbeelde wat gebruik word. Daar word nie genuanseerd gehandel oor die uitkoms van vergifnis nie. Die voorbeelde laat dit lyk asof iemand wat bitterheid gekoester het en eenmalig vergifnis in gebed uitspreek altyd onmiddellik bevry is van die bitterheid en die hartseer gevolge daarvan. Ervare beraders weet dat dit soms 'n lang pad is wat geloop moet word en dat vergifnis ' $n$ besluit voor God is waarna telkens bevestigend teruggekeer moet word wanneer iets die ou bitterheid weer oproep. Die benadering in die boek kan die gelowige wat worstel om onmiddellik geheel en al van bitterheid en ander sondes los te kom, moedeloos maak. Hoofstukke 6 tot 13 handel oor die pad nadat genesing plaasgevind het. 'n Verskeidenheid aktuele sake word aangespreek rondom die gelowige se stryd met die bose, okkulte, en oosterse praktyke. Hierdie sake word verstaanbaar en deeglik behandel en baie vrae word beantwoord vir die leser wat nie hiermee bekend is nie.

In die geheel is hierdie 'n bruikbare beginnersgids. Die waarde van die boek lê in die aktuele vrae wat beantwoord word en nie werklik waarop die titel aanspraak maak naamlik om genesing vir emosionele pyn te vind nie. 